SŪN MÈNGYÁO

Liaocheng University

1310543954@qq.com

MICHAEL KNÜPPEL

Liaocheng University

michaelknueppel@gmx.net

\title{
ON CHINESE HUI-MUSLIM ELEMENTARY VOCABULARY (2): FUNERAL TERMINOLOGY
}

Keywords: Hui Muslims, Sino-Arabic transcriptions, direct and indirect loans, Muslim funeral terminology

\begin{abstract}
With this paper the writers continue their series of articles on Chinese Muslim elementary vocabulary. As already mentioned in the first part, ${ }^{2}$ in most Chinese dictionaries the specific elementary vocabulary of Islam is omitted. The paper in hand deals with the funeral terminology of Chinese Muslim. ${ }^{3}$ In contrast to the prayer terminology, we can only find one direct borrowing in Sino-Arabic, but no Sino-Persian transcription (Arabic and Persian loanwords phonetically transcribed with Chinese characters) among the funeral terms. More often the common Chinese terms are also used in the specific Muslim context. Furthermore, it is obvious that the number of terms is somehow limited comparing to the prayer terminology.
\end{abstract}

(1) bin yí ting (殡仪厅) 'house for washing, shrouding and preparing the corpse before burial’ ( Arabic مخسلة للموتى maḩsala lilmawtā). Not all Muslim communities have such a house. It mainly depends on costs for running such an institution.

\footnotetext{
1 The paper in hand results from some fieldworks in the context of socio-linguistic research on the Hui-Muslim communities in the province of Shāndōng.

2 Sūn, Knüppel (2020a).

3 On the Hui Muslims' funeral customs cf. also Sūn, Knüppel (202ob).
} 
(2) chuān bù (穿布) 'the (three) shrouds for shrouding the corpse' ( Arabic كن kafin); cf. also $\rightarrow$ kè fán (克凡). While in other Muslim communities five shrouds are used for women, the Hui-Muslims in Shāndōng use only three.

（3） dà chuān bù (大穿布) 'the third of the three shrouds for shrouding the corpse' $(\rightarrow$ chuān bù [穿布] kè fán [克凡]) 'reaching from over the head till under the feet' ( Arabic لفاف lufäfa).

(4) huí guāng făn zhào (回光返照) 'the “death struggle”' ( Arabic سكرة الموت sakrat almawt); here no specific Hui-Muslim term is used, rather the common Chinese word occurs in this specific Muslim context.

(5) jià $z \grave{l}$ (架子) 'a kind of stretcher for the transport of the corpse from the house of the deceased's family to the cemetery' ( Arabic نش načs; this can point to both a stretcher and a coffin). Such stretchers are provided by the communities of the respective mosques. In this case the common Chinese word for such a tool is used in the specific Muslim context, too.

(6) jing lĭ (净礼) 'the ritual of washing the corpse' ( Arabic تغنسيل الميّت tagisil almayit, casl almayit). This follows a specific ritual. The corpse has to be washed three times, if needed, more times. For the several steps of it, there are no specific words. Here again we have no Muslim lexical item and common Chinese words are only used.

(7) jīng xiá (经匣) 'a transparent cooling container/coffin for keeping the corpse before transporting to the cemetery' ( Arabic غرفة حفظ الموتى ' gurfat hafz almawtā; this indeed points to a cooling chamber, e.g. in a hospital). Such containers/ coffins are owned by the mosque communities and have a cooling system to keep the corpse for some hours if needed.

(8) kăn jiān (坎肩) 'the first of the three shrouds for shrouding the corpse' $\rightarrow$ chuān $b u$ [ [穿布] kè fán [克凡]); 'reaching from the shoulders over the knees' ( Arabic إزار izära); in most Muslim communities it reaches from the hip to the ankles.

(9) kè fán (克凡) $\rightarrow$ chuān bù (穿布).

(10) ling shù rén (领属人) 'the "death prayer" spoken after the person deceased or before the burial’ ( Arabic صلاة الجنازة salāta al-ğināza).

(11) qi qiào (七窃) “seven orifices of the body" that have to be closed during or after the washing of the corpse" ( Arabic mahâriğ al-ğism "orifices of the body"'); these are the nostrils, ears, eyes, and mouth that have to be "stuffed" or covered (eyes) with cotton tampons. Among the Hui Muslims of Shāndōng the closing of other orifices of the body is not practised.

(12) qī qiào mŭ (七控米) 'the cotton tampons (filled with rice) to close or cover the "seven orifices of the body"' ( $\rightarrow$ qi qiào [七控]) 'during preparation of the corpse for burial' ( Arabic قطن qutun).

(13) shèng xing (圣行) 'funeral procession' ( Arabic تشيع الجنازة tašyīc al-ǧināza).

(14) shuĭ liū (水溜) 'shelf for the ritual washing of the corpse before burial' ( $\sim$ Arabic كخشبة الغسل kahšabat al-g்usli 'shelf/board, e.g. for washing the corpse').

(15) xiăo chuān bù (小穿布) 'the second of the three shrouds for shrouding the corpse' ( $\rightarrow$ chuān bù [穿布] kè fán [克凡]) 'reaching from the shoulders to 
the ankles' ( $\sim$ Arabic قيص kamīs); in most Muslim communities it reaches from the neck to the feet.

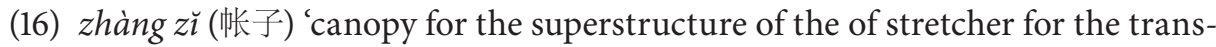
port of the corpse' ( $\rightarrow$ jià $z \breve{l}$ [架子]) 'made from cloth (often with broideries)'. For this the common Chinese word for the canopy is used in the specific Muslim context, too.

(17) zhĕ nà zé (者那则) 'the burial/funeral'; this is a Sino-Arabic transcription of Arabic الجنازة (al-)ğinazza (the lexeme is also used for transport/arrival of the corpse; in some Arabic societies the word مأتخ màtim is used for burial/funeral even though it is the lexical item referring to collective mourning/devotion.

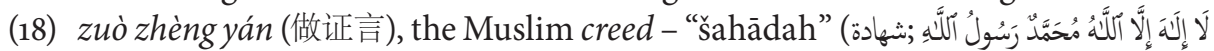
= "There is no god but God and Muhammad is the messenger of God"), which is repeated by the family and friends of a dying person during the death struggle to let the person passing away repeat it.

\section{References}

Sūn M., Knüppel M. 2020a. On Chinese Hui-Muslim elementary vocabulary (1): Prayer terminology. - Studia Linguistica Universitatis Iagellonicae Cracoviensis 137: 223-228.

Sūn M., Knüppel M. 2020b. Bestattungsbräuche bei den Hui-Muslimen Shāndōngs. Deutsche China-Gesellschaft - Mitteilungsblatt. Bulletin of the German China Association 63: 28-33. 
